\title{
Issues in or with Genesis 22: An overview of exegetical issues related to one of the most problematic biblical chapters
}

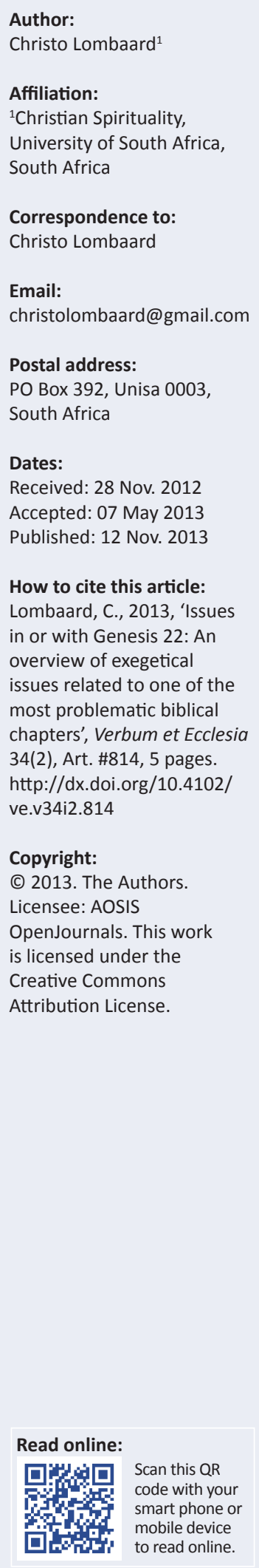

The understanding of the Akedah (Genesis 22) has since its very inception been contentious. The psychologically disturbing and theologically challenging account renders a series of exegetical and interpretative problems. Often methodology serves to hinder a fuller perception of the elements and aspects of the text, examples of which are given here relating to the opening phrase to the chapter, the choice of literary or historical placement implied by the exegete's choices on the opening phrase, the treatment of verses 15 to 18 (and, hence, verse 1 ) and the treatment of the morality (ethics and philosophy) involved with this text.

\section{Vir Jurie}

Die nabye oorsprong van hierdie bydrae lê in 'n uitnodiging om 'n doktorale seminaar vir studente aan die Protestantse Teologiese Fakulteit, Karelsuniversiteit Praag op 07 Mei 2012 te lei. Dié seminaar staan onder die leiding van Petr Sláma, wat onder meer 'n belangstelling het in die historiografie van sy plaaslike eksegetiese verlede (vgl. Sláma 2008:285-299), wat interessante ooreenkomste met die benadering in Jurie le Roux se werk toon (vgl. Le Roux 1993). Ook teenwoordig was sy kollega, Filip Čapek, wat my belangstelling in Genesis 22 deel (vgl. Čapek 2010:217-227) en 'n groepie doktorale studente. Daar was gou metodologiese ongemak tydens die seminaar: die standaard-voorgestane eksegetiese model by dié Fakulteit (een van drie teologiese fakulteite verbonde aan die Karelsuniversiteit te Praag) is ' $n$ grammaties-historiese benadering wat baie naby kom aan 'n soortgelyke benadering in Suid-Afrika (vgl. Van Deventer 2011:283305). Dié benadering is op 'n sterk ingeboude wantroue jeens histories-kritiese benaderings geskoei, maar met die kritiek wat dieselfde argumente van twee en drie dekades gelede opper, sonder om werklik kennis te neem dat historiese eksegese intussen al baie verander het. Dit is dus soortgelyk aan die kritiek wat dikwels in Suid-Afrika op hierdie metodes uitgespreek word. Daarteenoor verstaan ek die teksimmanente eksegetiese benaderings soos die narratiewe en struktuur-analitiese metodiek heel goed, van binne af, maar ek het 'n sterk voorkeur vir die histories-kritiese eksegese, ook vir konfessioneel-teologiese, oftewel piëteitsredes (vgl. Lombaard 2006b:18-31). Vandaar die metodologiese ongemak tydens die doktorale seminaar. Dit het moeite gekos om, in die skaduwee van naburige Duitsland, bakermat van die historiese kritiek, die gespreksgenote te oortuig dat histories-kritiese metodiek geloof nie hoef uit te sluit nie, maar, inteendeel, kan voed. Hierdie was 'n vae aanvoeling vanuit my vroeë teologie-studiejare, wat eers ryp geword het onder die intellektuele leiding van die een aan wie hierdie uitgawe opgedra word: Jurie le Roux (vgl. Lombaard 2006a:912-925). Die Praagse seminaar was dus 'n tipe déjà vu-ervaring: parallelle het geëggo tussen die bekende situasie tuis en die vreemde situasie naby die oewer van die Vltova. Pretoria het my voorberei vir Praag.

Die vroeëre oorsprong van hierdie bydrae lê in 'n proefskrif wat ek op Genesis 22 onder die leiding van Le Roux geskryf het (Lombaard 2009) en wat intussen in verdere navorsingstrajekte ontwikkel het. Deur die jare van daardie proefskrifskryf heen, was Le Roux my Doktorvater, werkgewer (dit was onder andere ook die beginjare van teo.co.za, die webdiens van die Fakulteit Teologie aan die Universiteit van Pretoria), professionele en intellektuele mentor, rolmodel en vriend. Die laaste drie is hy steeds; sal dit altyd ook wees. Ek dra daarom met groot graagte hierdie studie op aan Jurie le Roux, om op nog ' $n$ manier in woorde uit te druk wat die woordjie 'dankie' kwalik kan sê.

\section{A cracked jewel}

Genesis 22 has often been showered with praise for its narrative quality. Some of these 'accolades' are summarised by Bergen (1990:355), who calls this short chapter 'a crown jewel in the treasure box of [Old Testament] narrative'. However, does the text deserve such praise? For instance: can it be regarded as a well-developed 'short short story' (Lombaard 2009:100), if it takes rather restrictive adherence to a single methodology of exegesis not to see the other problems in the text not addressed, or smoothed over or ignored, by the particular method. The paragraph below offers an example of this. Whichever method is chosen and in whichever valuable ways a method can open the eyes for certain aspects of the text, care must be taken that the method is 
not absolutised. This could lead to the exegete being blinded to other aspects of the text. Such methodologically induced blindness is just a minor aspect of the much more complex and often still poorly understood, problem of the preceived method-truth correlation (cf. Gadamer 1975, a work that has been highly influential in Le Roux's thinking).

Therefore, characterisation of Genesis 22 in its structural, narrative, or text-historical composition as being of a certain aesthetic value, whilst valid, should remain aware also of imperfections. This, given that the form of aesthetic employed in the characterisation had been made clear by the evaluator (cf. Lombaard 2006b:23). Moreover, an exegete should remain aware of those aspects of the text which in no way fit with the chosen exegetical approach or evaluative framework. In addition, an exegete's eyes should not be closed to aspects of the text which assert themselves irrespective of the methodology followed (for instance, the occurrence of the hapax legomenon עקד [to set] in Gn 22:9, or the place name aetiology in verse 14 , both of which remain significant matters irrespective of exegetical approach). The text may be a gem, but flawless it is not. The jewel is cracked. Therefore, despite a choice for any given methodology, such a preference ought to keep to a certain openness towards other perspectives, acknowledging at the same time the limitations of the preferred perspective.

The latter implies that, if not all, then at least a substantial number of the textual elements or aspects have to be taken into account when studying a text. For this, proficiency in a number of exegetical methods is valuable. Of great necessity also is that one takes seriously the points made in studies done from approaches different to those one prefers. This will be an important aspect to keep in mind when following the argument below, as will again be indicated in the conclusion. What follows below, then, is not an attempt to draw up an exhaustive catalogue of the textual elements or aspects related to Genesis 22 that have been and continue to impact on the exegesis of this passage. For that, the format of a monograph would be more appropriate. Rather, only four points are indicated below as examples of how the elements or aspects of the text may be noticed. The purpose here is therefore to indicate exegetical-interpretative problems as illustrations and not to propose solutions or summarise research history related to Genesis 22 in any systematic way.

The four aspects of the text looked at in such a way, are: the opening phrase, the choice of literary or historical placement implied by the choices on the opening phrase, the treatment of verses 15 to 18 and the morality (ethics and philosophy) involved.

\section{The text - Genesis 22:1-24 (Akedah = Binding [of Isaac])}

Note that the breaks in spacing are for the sake of easily matching the verses on the left and right hand sides in Table 1. The exception to this pattern is at verse 20 , where it is universally accepted that a new pericope is introduced by the opening וַיְְ. [And it was] formulation.
No significant text-critical debates that may substantially alter the meaning of the account is found with Genesis 22. Nor are translation options greater than the order of nuance differences (such as in verse 10, where 'slaughter' or 'murder' may be substituted for ' $k$ ill') present that may have made for dramatically different renderings of the Hebrew into the target translation language.

In what follows, close attention is paid to each of the four textual elements or aspects indicated above.

\section{The וַיְִּ formulation}

The opening וַיְִּ formulation is a formulaic introductory phrase that often in the Hebrew Bible indicates the occurrence of a new pericope or account. As with other texts of the Hebrew Bible where this formula is found, some differences in the interpretation and translation of this formula can be found. These range from an indication of the beginning of a new event (e.g. in the King James Version, 'And it came to pass ...'), to indicating a flow of events (e.g. in the English Standard Version, 'After these things ...'), to a break in time between related episodes (e.g. in the New International Version, 'Some time later ...'). The idea of some kind of a distinct pericope or account being indicated by the וְיִִ formulation, is however universally accepted as far as the Genesis 22 text is concerned. The question that must be answered here, with the formulation occurring in both verse 1 and verse 20, is the strength that should be accorded the function of וַי here. Is it meant as indicating a completely separate account, relatively loose from its surrounding verses? Or is it rather a structural marker with which to tie these two pericopes in Genesis 22 into the rest of the surrounding chapters, namely as an intentional shaping technique? Or, as a third option, is here simply an indication of a steady, logical flow of the story, or the history, from the one account to the next? Semiotic, structuralist, narrative, literary-critical, form-critical or redaction-critical lenses will result in different views on this matter; however, all will have to consider explicitly the role of this formulation.

\section{The implied choice of literary or historical placement}

Along with this decision just indicated and depending on whether a more text-immanent or a more historical-critical inclined approach to the text is preferred (cf. Boase 2001:312335), a decision will have to be made on whether the primary context of the Genesis 22:1-19 $1{ }^{1}$ pericope is literary or historical:

- Text-immanent approaches will be inclined to insist more strongly that what occurs in the preceding and following texts may well have an interactive bearing on the respective meanings of the texts composing the whole and on the meaning of the whole of the textual body itself. Precisely what 'the whole' is defined as, will be a matter of choice of focus by the interpreter, and may with

1.As stated above, verse 20 is universally accepted as the beginning of a separate pericope. 
TABLE 1: Genesis 22 text in Biblia Hebraica Stuttgartensia and new revised standard version.

\section{Genesis 22: Biblia Hebraica Stuttgartensia

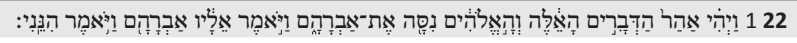

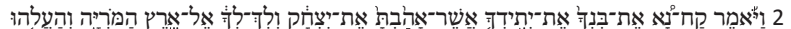

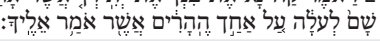

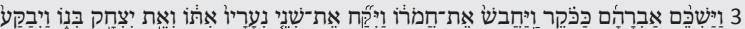

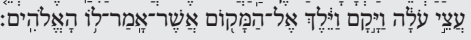

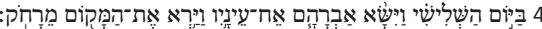 \\ 5

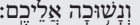

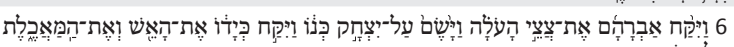

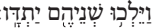

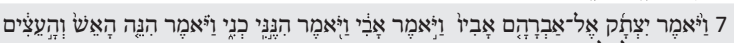

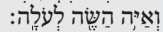 \\ 8}

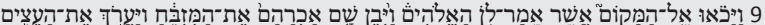

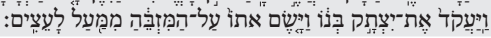

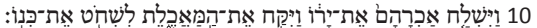

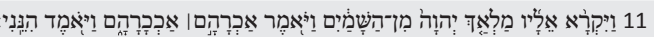

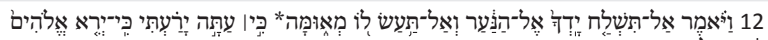

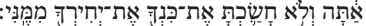

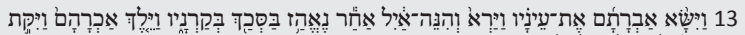

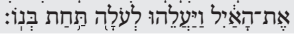

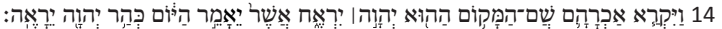

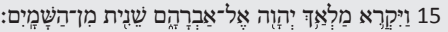

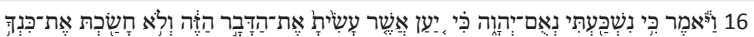
את־יחירד:

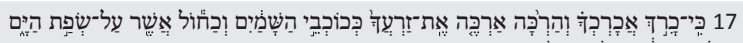

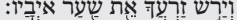

18

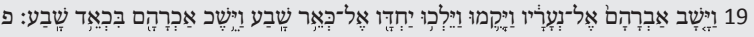

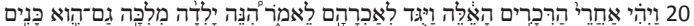

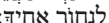

21

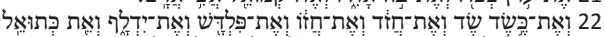

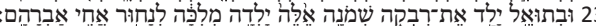

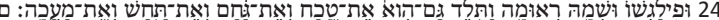

$22{ }^{1}$ After these things God tested Abraham. He said to him, 'Abraham!' And he said, 'Here I am.'

'He said, 'Take your son, your only son Isaac, whom you love, and go to the land of Moriah, and offer him there as a burnt offering on one of the mountains that I shall show you.'

${ }^{3}$ So Abraham rose early in the morning, saddled his donkey, and took two of his young men with him, and his son Isaac; he cut the wood for the burnt offering, and set out and went to the place in the distance that God had shown him.

${ }^{4}$ On the third day Abraham looked up and saw the place far away.

${ }^{5}$ Then Abraham said to his young men, 'Stay here with the donkey; the boy and I will go over there; we will worship, and then we will come back to you.'

${ }^{6} \mathrm{Abraham}$ took the wood of the burnt offering and laid it on his son Isaac, and he himself carried the fire and the knife. So the two of them walked on together.

'Isaac said to his father Abraham, 'Father!' And he said, 'Here I am, my son.' He said, 'The fire and the wood are here, but where is the lamb for a burnt offering?'

${ }^{8}$ Abraham said, 'God himself will provide the lamb for a burnt offering, my son.' So the two of them walked on together.

When they came to the place that God had shown him, Abraham built an altar there and laid the wood in order. He bound his son Isaac, and laid him on the altar, on top of the wood.

${ }^{10}$ Then Abraham reached out his hand and took the knife to kill his son.

${ }^{11}$ But the angel of the LORD called to him from heaven, and said, 'Abraham, Abraham!' And he said, 'Here I am.'

${ }^{12} \mathrm{He}$ said, 'Do not lay your hand on the boy or do anything to him; for now I know that you fear God, since you have not withheld your son, your only son, from me.'

${ }^{3}$ And Abraham looked up and saw a ram, caught in a thicket by its horns. Abraham went and took the ram and offered it up as a burnt offering instead of his son.

${ }^{4}$ So Abraham called that place 'The LORD will provide' as it is said to this day, 'On the mount of the LORD it shall be provided.'

${ }^{15}$ The angel of the LORD called to Abraham a second time from heaven,

${ }^{16}$ and said, 'By myself I have sworn, says the LORD: Because you have done this, and have not withheld your son, your only son,

${ }^{17}$ I will indeed bless you, and I will make your offspring as numerous as the stars of heaven and as the sand that is on the seashore. And your offspring shall possess the gate of their enemies,

${ }^{18}$ and by your offspring shall all the nations of the earth gain blessing for themselves, because you have obeyed my voice.'

${ }^{9}$ So Abraham returned to his young men, and they arose and went together to Beer-sheba; and Abraham lived at Beer-sheba.

Now after these things it was told Abraham, 'Milcah also has borne children, to your brother Nahor: ${ }^{21} \mathrm{Uz}$ the firstborn, Buz his brother, Kemuel the father of Aram, ${ }^{22}$ Chesed, Hazo, Pildash, Jidlaph, and Bethuel.' ${ }^{23}$ Bethuel became the father of Rebekah. These eight Milcah bore to Nahor, Abraham's brother. ${ }^{24}$ Moreover, his concubine, whose name was Reumah, bore Tebah Gaham, Tahash, and Maacah. the Genesis 22 text be as wide as the Abraham cycle, the patriarchal narratives, the Pentateuch, the Enneateuch, the Hebrew Bible in total, the Hebrew Bible along with mishnaic and/or midrashic interpretations, the Christian Bible as a whole, with or without the interpretations from the early church, or the Scriptures of the three Religions of the Book taken together (cf. e.g. Bekker \& Nortjé 1995:454-464; Dozeman, Römer \& Schmid 2011; Noort \& Tigchelaar 2002) - to limit the possibilities for the moment just to relative antiquity.

- Historical-critical inclined readings would on their part try to find not a literary, but a possible, and a passable, socio-historical context within which the accout could have arisen and within which the Akedah can therefore to be understood. Five of these (summarised in Lombaard 2013) have been proposed on the Akedah, which respectively regard Genesis 22:

- as early-Yahwistic prohibition text, either warning against or putting to an end child sacrifice that may have occurred within ancient Israel (cf. e.g. Boehm 2004:145-156)

- as aetiological text, with the purpose of the whole account being to root imaginatively two matters, namely the choice in verse 2 of Moriah as traditional sacrificial site and the place name explanation offered in verse 14 (cf. e.g. Bremmer 2002:35)

- as initiation foundation, namely as a myth accompanying the rites of passage of cult-clan leaders (represented by Abraham), initiates (represented by Isaac) and novitiates (represented by the young men in verses 3 to 5 and 19; cf. White 1991:187, 203 \& 1979:1-30)

- as theodicy, namely as a more radical precursor to the Job book's theological wrangling with the problem of suffering (Veijola 2002:127-144)

- as a closing salvo text in the internecine struggle for dominance amongst the patriarchal groups, in which the Abraham-Yahweh group with this text asserts its dominance (Lombaard 2011:470-486 \& 2008:907-919; cf. Davies 2000:21-40).

Two observations may be made from this. The first observation is that neither the text-immanent nor the historical-critical approaches offer simplicity. Both broad approaches offer within themselves, respectively, a range of extant exegetical options (and always the possibility of more ...), with the decisions taken that may equally 
easily lead to almost paradigmatic exclusiveness being associated with the own, preferred view. This does not yet take cognizance of the usual juxtaposition view, if these two broad approaches are be pitted against each other, thus enlarging the perceived gulf between these two broad exegetical approaches.

The second observation relates to implication: already these first-order decisions, which seem relatively trivial at the outset, have far-reaching hermeneutical implications. The choice on whether to view textual or historical context as primary focus area for reading the Akedah account, immediately implies paradigm choices. Moreover, such decisions have previously been implied by one's stance on opening וַיְּ formulation, indicated above. The conclusion remains inescapable, that what seems to be very minor initial decisions taken by an exegete, is already so thoroughly theoretically imbedded, that it remains impossible to read a text 'as it is', as if an a-theoretical reading were possible (cf. Le Roux 2001:444-457).

Rather than taking such decisions without recognising that it has been done, and hence entering into an interpretative mold reflexively, and unreflectedly, it remains intellectually more honest and hence more scholarly for exegetes to acknowledge explicitly how these textual elements or aspects have been decided on and will therefore be treated.

\section{Verse 15-18 (and verse 1's

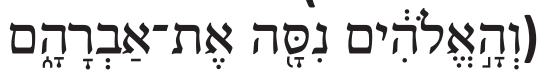

The third of the elements or aspects of the Genesis 22:1-19 text considered here, as illustration of how a textual element must be recognised in order to be treated deliberately, are verses 15-18. These verses constitute a theological interpretation or interpolation, depending on one's view, of the Akedah. For the moment to employ redaction criticism and narrative analysis as examples of, respectively, historical-critical and text-immanent exegetical approaches, it is clear that these two methods clearly do not do the same thing. However, can they even see the same thing? This leads to the question: Can the textual elements or aspects of Genesis 22:1-19 truly be taken seriously if they do not appeal directly to the interests of the preferred exegetical method? Redaction-critical analyses cannot but regard Genesis 22:15-18 (italicised in the English translation above) as a very early, though later than the composition of the main text, theologising insertion into the Genesis 22:1-14 and 19 text (cf. particularly Moberly 1988:302-323). Can such analyses however recognise that the resultant text, with verses 15-18 included, indeed has a certain narrative richness to it, blending as it does narrative and theology (or story and lesson) into a substantive whole? Equally, though, as much as narrative readings of this account appreciate the qualities of Genesis 22:1-19 as-is, namely as a well-told story (e.g. Berman 1997; cf. Tolmie 1999), it must still be conceded that verses 15-18 do break recognisably with the succinctness that is characteristic of the rest of the account, also here incorporating another stylistic voice.
If this textual element or aspect is recognised and its treatment by the exegete acknowledged, this has immediate

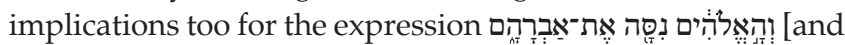
God tested Abraham] the phrase in verse 1 also italicised in the English translation above. With verses 15-18 seen as an integral (or at the very least, integrated) part of the final Akedah text, the reference to a test for Abraham in verse 1 remains unproblematically part of this whole. However, if Genesis 22:15-18 is seen as a theologising insertion to Genesis 22:1-14 and 19, then it comes naturally to recognise the same theology in the test reference of verse 1 , and hence to regard it too as an interpolation.

Again, here, the way in which the text is approached has direct implications for the way in which the theology in it is viewed, namely either as theology within the account, or as theology appended to the account.

Although the latter may initially be seen as a relatively benign distinction, it has rather stark consequences in, once again, a wider context. This wider context here is philosophical, namely when the morality of or within the Akedah is taken into consideration.

\section{Morality, ethics and philosophy}

The psychologically disturbing nature of the Akedah account is probably the cause for the widespread public recognition of this story, both within and outside religious circles (Lombaard 2009:14). With the narrative taken at face value, the idea of child sacrifice is already troubling enough. Add to that the Divine instruction to commit this deed, despite a kind of rescue in verses 11-13 that is analogous to the Deus ex machina device in classical dramas and the whole morality of any religion related to such a kind of godhead can be drawn into question (as has indeed again been done by Dawkins 2006:242-243). This is particularly the case given that life, love and peace are the mainstays usually associated with religion and with God. What is more, though, the father of three faiths colludes in this developing atrocity, namely by misleading his son Isaac in verse 8 , thus breaking (at the very least the spirit of) the eighth commandment. These three dubious acts leave in the public mind not much high morality to which to strive.

Yet, many readings of the Akedah do exactly that: stressing morality in particular, namely by emphasising the obedience of Abraham as a virtue (thus following precisely the theologising in verses 1 \& 15-18, italicised in the English text above). This is followed through by either ignoring the troublesome three aspects above, or ascribing them to part of God's master plan, in order fully to test Abraham (cf. e.g. Čapek 2010:217-227; Sekine 2007; Miyamoto 2006:81-162; Neef 1998:45-62 and Kruger 1991:187-200 for various takes on these ethical and philosophical matters). This is most often the interpretative tack or theological line taken by text-immanent readings. However, all the historical-critical explanations of the Akedah account as a whole (summarised above), can best be understood as apologies for precisely 
this immorality widely associated with the Akedah account. These exegetical proposals offer different readings by suggesting alternative socio-historical settings, which on their part render understandings that are much less disturbing to any modern ethics based on love or on philosophical conceptions about God that are related to goodness. Thus, the Akedah text, the Bible, religion and God is per inference freed by historical-critical proposals from the very negative judgments at times prompted by Genesis 22:1-19.

\section{Sights and insights}

Many other possible elements and aspects of the Akedah text could have been indicated along with those above, and related not only to the text itself, but also the methodological frameworks brought to it, as has briefly been done above. For instance, a semiotics reading focussing on the signs in the text may make much of a seldom-noticed aspect of it, namely the absence of Sarah from the narrative (cf. Setio 1993:49, 157-166, following Trible 1991:170-191). However, the points have been made strongly enough, with the four examples above:

- that methods shape vision

- that multiple methods 'see' different elements and aspects of a text, or 'see' the same ones but view them quite differently

- that this does not imply that combining diverse methods will make for better exegesis, because the methods are often not mutually compatible; but, returning to the conclusion in point 2 above

- that the responsibility lies with exegetes to read widely, also outside the own usual exegetical framework, in order to be enriched by these other sights and insights

- that seemingly smaller choices are already embedded in strong exegetical and interpretative presuppositions, as demonstrated in points 4 to 7 , and entail that smaller decisions have wider repercussions, influencing the rest of one's interpretations.

For me to present these insights as a dedication to Jurie le Roux, is a privilege. All of these intuitions stand in the wake of the intense discussions we have had and stem from what I have learnt from him in his writings and classes. To have him as colleague and friend is indeed a blessing.

\section{Acknowledgements Competing interests}

The author declares that he has no financial or personal relationship(s) that may have inappropriately influenced him in writing this article.

\section{References}

Bekker, C.J. \& Nortjé, S.J., 1995, 'Die gebruik van die offer van Isak as 'n motief vir die

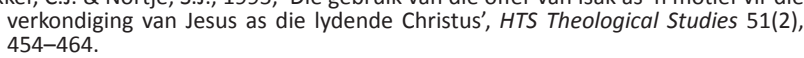

Bergen, R.D., 1990, 'The role of Genesis 22:1-19 in the Abraham cycle: A computerassisted textual interpretation', Criswell Theological Review 4(2), 313-326.
Berman, L.A., 1997, The Akedah: The binding of Isaac, Jason Aronson, Northwale.

Boase, E., 2001, 'Life in the shadows: The role and function of Isaac in Genesis synchronic and diachronic readings', Vetus Testamentum 51(3), 312-335. http:// dx.doi.org/10.1163/15685330152913594

Bremmer, J.N., 2002, 'Sacrificing a child in ancient Greece: The case of Iphigeneia', in E. Noort \& E. Tigchelaar (eds.), The sacrifice of Isaac. The Aqedah (Genesis 22) and its interpretations, pp. 21-43, Brill, Leiden.

Boehm, O., 2004, 'Child sacrifice, ethical responsibility and the existence of the people of Israel', Vetus Testamentum 54(2), 145-156. http://dx.doi. org/10.1163/156853304323018855

Čapek, F., 2010, 'Philosophical Discourse on Genesis 22 - Akedah reflected by Kant, Fichte and Schelling', Communio Viatorum 52(3), 217-227.

Davies, P.R., 2000, 'Abraham and Yahweh: A case of male bonding', in H. Shanks (ed.) Abraham \& family. New insights into the patriarchal narratives, pp. 21-40, D.C. Biblical Archaeology Society, Washington.

Dawkins, R., 2006, The God delusion, The Bantam Press, London.

Dozeman, T.B., Römer, T. \& Schmid, K., 2011, Pentateuch, Hexateuch, or Enneateuch. Identifying literary works in Genesis through Kings, Society of Biblical Literature, Atlanta.

Gadamer, H.G., 1975, Wahrheit und Methode. Grundzuge einer philosophischen Hermeneutik, Mohr, Tübingen.

Kruger, H.A.J., 1991, 'God tests Abraham: The command to sacrifice Isaac', Ned. Geref. Teologiese Tydskrif 32(2), 187-200.

Le Roux, J.H., 2001, 'No theory, no science. (or: Abraham is only known through a theory)', Old Testament Essays 14(3), 444-457.

Le Roux, J.H., 1993, 'A story of two ways. Thirty years of Old Testament scholarship in South Africa', Old Testament Essays, Supp. res. 2.

Lombaard, C., 2013, 'Genesis 22', in M. Roncace (ed.), Global perspectives on the Bible, New Jersey, Prentice Hall, Pearson.

Lombaard, C., 2011, 'The Patriarchs and their Pentateuchal references: Outlines of a new understanding', Tydskrif vir Semitistiek / Journal for Semitics 20(2), 470-486.

Lombaard, C., 2009, Isaac in the Old Testament. New interpretation from Genesis 22 , based on hermeneutical-methodological and exegetical investigations, DD dissertation, University of Pretoria, Pretoria.

Lombaard, C., 2008, 'Isaac multiplex: Genesis 22 in a new historical representation', HTS Theological Studies 64(2), 907-919.

Lombaard, C., 2006a, 'Teks en mens. JH le Roux se lees van die Bybel binne die konteks van hoofstroom-eksegese in Suid-Afrika', Old Testament Essays (Special Edition) 19(3), 912-925.

Lombaard, C., 2006b, 'The Old Testament between diachrony and synchrony: Two reasons for favouring the former', Journal for Semitics / Tyskrif vir Semitistiek 15(1), 18-31.

Miyamoto, H., 2006, 'Aburahamu no junan to tasha no chihei - Hyōhaku no monogatari kara hayatorogia (heburaiteki sonzairon) teki kyōsei [The suffering of Abraham and the horizon of the Other - from bleached narrative to hayatological (Hebraic ontology) symbiosis]', in H. Miyamoto, T. Onuki \& T. Yamamoto (eds.) (Hebraic ontology) symbiosis]', in H. Miyamoto, T. Onuki \& T. Yamamoto (eds.),
Junan no imi: Aburahamu, lesu, Pauro [ The meaning of suffering: Abraham, Jesus, Junan no imi: Aburahamu, lesu, Pauro [ The meaning of
and Paul], pp. 81-162, Tokyo University Press, Tokyo.

Moberly, R.W.L., 1988, 'The earliest commentary on the Akedah', Vetus Testamentum 38(3), 302-323.

Neef, H-D., 1998, 'Abraham! Abraham!' Gen 22,1-19 als theologische erzählung ['Abraham! Abraham!'Gen 22:1-19 as a theological narrative]. Journal of Northwest Semitic Languages 24(2), 45-62.

Noort, E. \& Tigchelaar, E. (eds.), 2002, The sacrifice of Isaac. The Aqedah (Genesis 22) and its interpretations, Brill, Leiden.

Sekine, S., 2007, 'Philosophical interpretations of the sacrifice of Isaac', paper read at the congress of the International Organisation for the Study of the Old Testament, Ljubljana, Slovenia, July 2007.

Setio, R., 1993, 'Reading the Akedah narrative (Genesis 22:1-19) in the context of modern hermeneutics', unpublished PhD thesis, University of Glasgow, Glasgow.

Sláma, P., 2008, 'Beyond, before and within the text of the Bible; on the history and its importance for Old Testament theology: The case of Slavomil C. Daněk (18851946)', Communio Viatorum 50(3), 285-299.

Tolmie, D.F., 1999, Narratology and biblical narratives: A practical guide, International Scholars Publications, San Fransisco.

Trible, P., 1991, 'Genesis 22: The sacrifice of Sarah', in J.P. Rosenblatt \& J.C. Sitterson (eds.), Not in heaven: Coherence and complexity in bliblical narrative, pp. 170191, Indiana University Press, Bloomington.

Van Deventer, H.J.M., 2011, 'Grammaties-historiese eksegese: Quid est et quo vadis?', In die Skriflig 45(2\&3), 283-305.

Veijola, T., 2002, 'Abraham und Hiob. Das literarische und theologische Verhältnis von Gen 22 und der Hiob-Novelle', in C. Bultmann, W. Dietrich \& C. Levin (Hrsg.), Vergegenwärtigung des Alten Testaments. Beiträge zur biblische Hermeneutik (Festschrift für Rudolf Smend zum 70. Geburtstag), pp. 127-144, Vandenhoeck \& Ruprecht, Göttingen.

White, H.C., 1991, Narration and discourse in the book of Genesis, Cambridge University Press, Cambridge.

White, H.C., 1979, 'The initiation legend of Isaac', Zeitschrift für die Alttestamentliche Wissenschaft 91, 1-30. http://dx.doi.org/10.1515/zatw.1979.91.1.1 